\title{
Difficult Factors in Application of Derivative Financial Instruments Accounting - Experimental Study in Vietnam
}

\author{
Hanh Nguyen Thi Hong ${ }^{1}$, Thuy Nguyen Thu ${ }^{2}$ \\ ${ }^{1}$ Ho Chi Minh City Open University, 97 Vo Văn Tan, Dist. 3, Ho Chi Minh City, Viet Nam \\ ${ }^{2}$ Nha Trang University, 2/1A Đang Tat, Nha Tang, Khanh Hoa, Viet Nam
}

\begin{abstract}
Research refers to problems about accounting for derivative financial instruments for enterprises in Vietnam by modeling study factors impact in applying the derivative financial instruments. The results showed that each independent variable has its own impact with different intensity on the dependent variable, including factors for regulatory, human - accountants, human - managers, market, are positively impact; also factors for training, retraining and technology to impact negatively in applying the derivative financial instrument accounting. From the results of the study, author has drawn implications and identified two key factors, which are regulatory and human - accountants.
\end{abstract}

Keywords: Accounting for derivative financial instruments, nature of accounting, difficult factors, etc

\section{Introduction}

Globalization trend with an increase in trade and international capital flows and the volatility of commodity prices, interest rates and exchange rates, etc. are the causes that can lead to potential risks for Vietnam's enterprises. Therefore, in order to prevent risks and uncertainties threatening business operations, the businesses look to derivative contracts for hedging and enhancing enterprise value (Fatemi A, C. Luft, 2002). An integral part of derivatives trading activities is the accounting for derivative financial instruments.

To ensure the quality and enhance the reliability of accounting information directly related to the derivatives financial instrument applied in businesses, relevant regulations have to be issued promptly, closely and synchronously. Conversely, the absence of accounting regulations does not only guarantee the quality of accounting information but also causes difficulties for those involved as practitioners, legislators, users, and so on.

To make sure that derivative market activities run smoothly, businesses are advised to review the rules on derivative financial instruments accounting. The absence of accounting regulations about derivative financial instruments can be problematic for businesses when joining derivative transactions as well as accounting.

With the above analysis, the researchers want to find out the difficult factors as well as determine the intensity impact of these factors on derivative financial instruments in Vietnam.

\section{Background and Study Models}

\subsection{Background}

2.1.1 Derivative financial instruments activities in Vietnam

Number and value of transactions on derivative financial instruments in the market Vietnam is still quite modest, about $\$ 150$ million (2013), compared to other markets like Singapore 54 billion (10/2012). The reason is that Vietnam enterprises are not aware of the importance of using derivative financial instruments to hedge the volatility of commodity prices and create a channel of modern speculation (Schofield, 2007).

Vietnam is in the process of regional economic integration and the world, opening up opportunities as well as challenges for enterprises. The use of derivatives for hedging risks in business activities of the enterprise is inevitable. Through discussions, consulted experts in the field, applying the derivative financial instruments into practice in of the current market economy in Vietnam is very difficult because of the followings: (i) Financial, currencies, commodities markets in Vietnam have not developed sychronously; (ii) The legal system is not complete; (iii) The qualifications, knowledge, awareness, understanding of derivative instruments of managers as well as the executors, and risk prevention issues are still low; (iv) Lack of systems to provide information on derivative financial instruments; (v) Process of data entry transactions, accounting, tracking, and control is limited.

2.1.2 Literature review of accounting for derivative financial instruments in Vietnam

The world has gone through nearly 20 years of derivative financial instrument accounting since IAS 32 effective introduction and implementation on 01/01/1996. Due to the complicated nature of the derivative financial instruments as well as practical application, such asprocess in classification, recognition, measurement, and disclosures, this standard has 


\section{International Journal of Science and Research (IJSR) \\ ISSN (Online): 2319-7064 \\ Index Copernicus Value (2013): 6.14 | Impact Factor (2015): 6.391}

been repeatedly amended and supplemented and basically were applied by different countries in the world.

In Vietnam, the legal documentation system directly related to derivative financial instrument accounting issued by the Ministry of Finance and the State Bank (for the banks), includes as follows:

+ The Ministry of Finance issued VAS 01 - General Standard; VAS 10 - Effect of exchange rate changes; VAS 21 - Presentation of financial statement; VAS 22 Presentation Additional financial statements of banks and similar financial institutions; Circular No. 200 dated 12/22/2014 and Circular No. 53 dated 03/21/2016 on amendments and supplements to Circular 200; Circular 210 dated 6/11/2009 providing guidelines on presentation of financial statements and information for financial instruments.

+ State Bank issued Decision 29 amending, supplementing and canceling some accounts in the system of accounts of credit institutions in accordance with Decision 479 and Decision 807 of the SBV Governor issued; Official Letter No. 7404 dated 08/29/2006 providing guidelines on accounting entries in currency derivative operations; Decision 16 regulating interpretation of financial statements.

Thus, for credit institutions, based on the current regulations, the time of initial recognition of currency derivatives is the effective date of the contract, the time of the recognition removal is the contractual settlement date. Then, the unit regularly reassesses and records in accounting books according to fair value, and determines business results appropriately on the financial statements. The disclosure of information on financial reporting for derivative has been comprehensively stipulated by the State bank. For nonfinancial firms, there have been no specific guidance documents, directly on the accounting treatment, such as user accounts, accounting, evaluation, presentation indicators related to purchase transactions/sold, traded derivative financial instrument on the financial statements. Therefore, in accounting for derivative transactions, only profit or loss actually incurred are recognized, whereas at the date of the financial statements when profit or loss which has not incurred yet, it is not recognized since there is insufficient evidence. For example, a gasoline business now buys a futures contract at $\$ 1$ billion; however, at the date of setting the financial statements, the value of the bought goods may be reduced, with only $\$ 950$ million, or may be raised to 1.15 billion but accounting book still only represents one billion. This fact makes it impossible to reflect the real value of bookkeeping system and create loopholes for false profit status, real holes (or vice versa), different from the accounting reports of enterprises.

Conclusion: Through the short overview of derivative financial instruments and derivative financial instrument accounting in Vietnam, the author finds that (i) derivative financial instruments: there have been a lot of difficulties from the market, the legal system, awareness, knowledge and understanding of administrators and bookkeepers, the system information on derivative financial instruments. (ii) accounting for derivative financial instruments: despite the regulations, circulars, guidelines provided, accountants still face problems in the accounting process, especially for nonfinancial enterprises.

Associated with many difficulties from the derivatives market, the use of derivative financial instruments of the market participants, the derivative financial instrument accounting with many difficulties in the current globalized economyis unavoidable. The important issue now is to identify core difficult factors, and find the causes of them and then apply international derivative financial instrument standards of accounting systems into Vietnam.

\subsection{Research Models}

According to Davis et al (1982), there are many different views about the nature of accounting, such as informative nature, economic nature, political nature and social nature. The views do not exclude from one to another, but complement and support each other to develop the study of accounting to a deeper, more extensive level.

\subsubsection{Market factor}

The concept of the social nature of accounting (Davis et al 1982), accounting must contribute benefits to society and maintain the sustainable development of society. The theory of social benefits derived from the failure of the market since the barriers prevented enterprises from entering the market for information asymmetry.

Signaling Theory was formed in 1973, from the economics of the market conditions with asymmetrical information (Spence, 1973, Tirole 1988). In the field of accounting, information asymmetry leads to two problems: (i) Accounting information is not fully presented in the financial statements by businesses, or possibly information publicized by businesses does not guarantee the quality for the information users. This status may be due to the incompetent administrators to implement financial statements with qualified information; (ii) Motives behind administrators's decisions in the information disclosure. Both of these problems do not only cause obstacles for the people to use accounting information in the financial statements of economic decision-making, but also lead to the underdevelopment of the market. In a market economy, the monetary and capital markets and commodity markets with mutual supports and additions, the underdeveloped market will spread its effects on the remaining markets.

The view of Davis et al (1982) is that accounting is a special commodity, relating to the public interest. If a product is unable to meet quality requirements, and operated in an inefficient market, will it be circulated well. This shows a relationship between the goods - accounting and market factor.

In short, to serve social interests, if the reporting unit is aware usefulness of accounting information and able to provide more information with more reliability and more transparency, the market will operate more efficiently. In contrast, the false accounting information does not only affect market participants, making the market less efficient operation, but also influence the stability of the entire 


\section{International Journal of Science and Research (IJSR) \\ ISSN (Online): 2319-7064}

Index Copernicus Value (2013): 6.14 | Impact Factor (2015): 6.391

economy, from which leads to inefficiency in the work of derivative financial instrument accounting.

\subsubsection{Regulatory factor}

However, the accounting information is easy made false due to the information maker's subjective bias, or the motives or purposes of the managers in the disclosure of information causes the information asymmetry.

In Vietnam, the state is held to elaborate and promulgate regulations relating to accounting to meet the needs for all economic sectors, the business sector, and the general interest of society. But it is very difficult to control if the business ensures compliance with all accounting rules and regulations or not and how the level of compliance is, although business has been independently audited.

According to Davis et al (1982), accounting is to record events in the past, to reflect economic realities, and to be a language of businesses. Accounting must therefore fully reflect the accounting data and this data must comply with the enacted rules and regulations.

Information asymmetry stems from a regulation but (i) the level of knowledge, understanding, different expertise will leads to different accounting results; or maybe (ii) comes from various interests, through the behavior of managers and accounting practices, and the result will be also different. The observation of these objects are not easy, it is required to clarify the following issues: legal factors have relationship with accounting practices as well as the associated objects such as control or internal audit. This shows the relationship between the accounting and regulatory factors.

\subsubsection{The human factor - Managers}

With the economic nature of accounting (Davis et al, 1982), accounting is a special commodity related social benefits, thus accounting must be controlled through regulations rather than giving administrators the freedom to choose accounting policies or exercise the financial statements freely.

According to resource-based view theory (Wernerfelt, 1984), it's advised to focuse on analyzing the resources: (i) tangible resources as financial resources are the source of the owners' capital and financing; (ii) Intangible resources can be knowledge and skills of managers and employees. This theory is the basis for businesses to make decisions to create business effective business performance. elationship between managers and shareholders shows that managers tend to avoid risks, put efforts within certain ranges so long as to create added value for the business, which may push administrators to choose the safe strategies, and may lead to that managers will seek to have impact on the accounting system in order to achieve their objectives or financial situation of the unit in difficult financial situation.

An issue that needs clarification of the relationship between benefits and costs (social nature of accounting, Davis et al, 1982). Benefits are gained from the use of derivative and cost must be spent on making them. Either managers only want to inform what they have rather than spend more on the accounting work. As a result, there will be no involvement and cooperation between managers and accountants, or they will not be willing to participate in derivative instruments for hedging, or they will tend not to want to learn about this activity, or if they do, the participation will be at very low level, which can not guarantee the safety assurance, or they will not fully aware of the usefulness of this tool. Therefore, managers factor needs studying in the current research model.

\subsubsection{The human factor - accountants}

To ensure the benefits of shareholders in particular and of society in general, Vietnam Accounting Law 2015, coming into effect from 2017, stipulates that: (i) Accounting tasks: Collecting, processing information management, accounting data by audience and content of accounting work, according to accounting standards and accounting regulations; Providing information, accounting data as prescribed by law; (ii) Accounting requirements: Fully reflect economic operations, timely financial, accounting data input into accounting documents, accounting books and financial statements; Providing honest information, objective, nature of the content and value of economic and finance transactions; (iii) the standards and responsibilities for accountants: Accountants are required to have professional qualifications and skills in accounting, to be ethical, and responsible for compliance with the provisions of the law on accounting.

From these rules, it can be seen that accountants are under high pressure from the regulations for the profession, ensuring a balance between interest groups, and understanding the complexity of derivative financial instrument data. In addition, they must and meet all the regulations and comply with the principles and the regulations on accounting transactions and derivative financial instruments.

\subsubsection{Training and retraining factors}

Economic perspective views accounting as a commodity. Goods must be circulated, valuable and quality-assured in line with its value. In accounting perspective, commodities show that the accounting information affects markets through the nature of supply and demand. Accounting information is provided through financial statement, and its users demands accounting information to be qualified. On the other hand, closer to accounting law and governed by the principles, accountants shall comply with regulations but is dependent on human subjectivity (Stamp, 1981). Subjectivity here is that the accountants who may not properly understand the nature of the business, or not properly understand the provisions and principles will lead to misleading practice on business due to the practitioner's subjectivity. To help the owner achieve the economic benefits when using accounting information and sources of information, and ensure the quality of the information, the training and regular retraining for accountants in business is necessarily provided. The tendency to rely on the principles and regulations for the accounting of economic operations in units (sometimes complicated) requires practitioners and report makers to regularly update, upgrad and enhance expertise, to perform as well as to do the management consultancy. 


\section{International Journal of Science and Research (IJSR) \\ ISSN (Online): 2319-7064}

Index Copernicus Value (2013): 6.14 | Impact Factor (2015): 6.391

\subsubsection{Technology - communication - accounting software factors}

With globalization stage 3.0, the progress of science and technology, the major changes and the boom of information technology - computers, internet systems, and processing software facilitate market participants access to the internet quickly and capture market information, or enable accounting information of a unit to be faster. In addition, the accounting information is considered to have major impacts on the allocation of resources in the economy. Through that, accounting information has influences on market prices (Gonedes \& Dopuch, 1974). Accounting information systems encourages accountants to know how to handle the information, how to adjust the frequency, speed, redundancy and other forms of information transmitted.

Through theoretical research and discussions with experts, authors synthesize, analyze, and build a number of difficult factors accounting for derivative financial instruments in Vietnam namely: (i) market factor; (ii) regulatory factor; (iii) the human factor - managers; (iv) The human factor accountants; (v) training and retraining factors; (vi) technology - communications - accounting software factors and setting up indicators of these factors, and the authors present a model of the proposed study as follows:

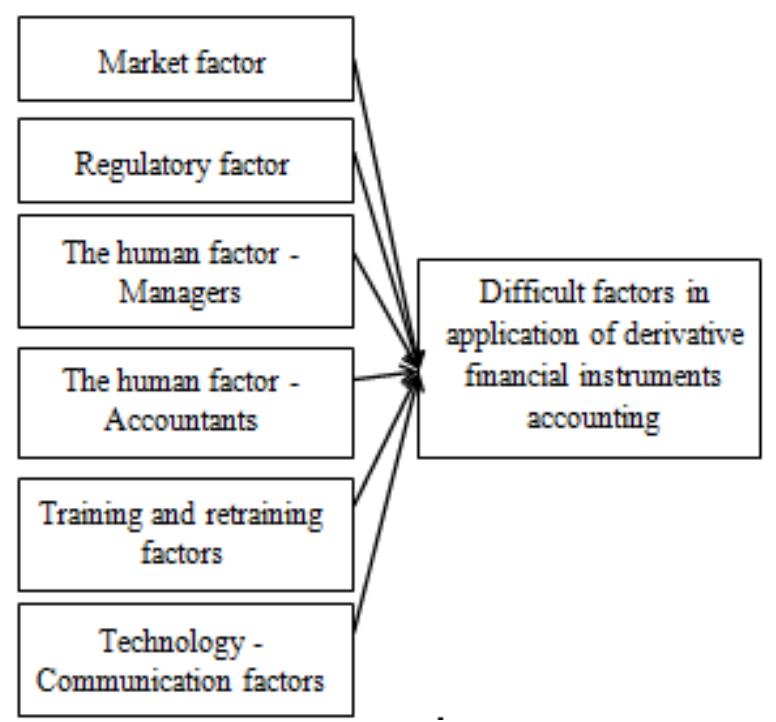

Figure 1: The proposed research model - Difficult factors in application of derivative financial instruments accounting. Source: Author compiled

\section{Methodology Study}

\subsection{Test investigation}

Based on the scale which has been formed consisting of 32 indicators measuring 6 concepts and 5 Likert scale distance is used, the researchers conducted experiments with 10 observations. Purpose of the first test is to check the compatibility of the items asked. The result after the test investigation, the questionnaire is completely qualified for use in large scale surveys to conduct formal research.

\subsection{Subjects Sampling}

In the present conditions of Vietnam's economy, enterprises involved in using derivative financial instruments is very limited and find it difficult to access these instruments. Thus, overall the survey of real businesses use derivatives to participate is difficult to determine. Therefore, the authors selected sampling method selectively only now have been using derivatives financial instrument.

In this study, the authors selected only enterprises using derivatives including financial and nonfinancial (this object is very difficult to access) businesses, while respondents must have knowledge of derivative financial instruments. Hence, the authors chose sampling subjects selectively through questionnaires sent directly, or through the mail, or over the phone to accounting practices at the enterprise.

\subsection{Sample Size}

To make the data analysis results reliable enough, it's necessary to collect at least 5 observations of 1 observed variable (Nguyen Dinh Tho, 2012). Within the scope of this study, the authors propose a model with 32 variables, the corresponding observation will be $n=160$. After a preliminary data analysis (Cronbach Alpha) the model remained 22 variations. So the minimum sample size is $22 *$ $5=110$. But in Vietnam there were not many units using derivatives, the author collected only 97 enterprises (financial and non-financial), with real conditions: (i) the overall number of small units, (ii) it's difficult to access to the object observed (who represents companies to complete the questionnaire), (iii) through the process data analysis, observed variables which were disqualified were eliminated, the model remained only 22 variables, so the defined sample is 110 at minimum, but in fact after the questionnaire (500 observations) delivered, the collected are 115 observations, after cleaning, there were 97 observations preliminary remaining, interim eligible to proceed to the analysis.

\subsection{Data Processing Method}

- Cleaning the data: the results after the survey and data cleaning was 97 valid questionnaire observations, meeting the requirements of the relative sample size needed for research.

- Data encryption: data is encrypted and entered into a data processing software SPSS 16.0.

\section{Research Results}

\subsection{Analysis using Cronbach Alpha coefficients}

To ensure the reliability of the items asked in the questionnaire, the researcher used Cronbach Alpha. Results analyzed using Cronbach Alpha coefficients repeatedly underwent the variable elimination (eliminate one by one variable) to achieve the final satisfactory result, (also 22 observed variables) qualified for the next analysis step. 


\section{International Journal of Science and Research (IJSR) \\ ISSN (Online): 2319-7064}

Index Copernicus Value (2013): 6.14 | Impact Factor (2015): 6.391

\subsection{Exploratory Factor Analysis - EFA}

Exploratory factor analysis was performed in following order: (i) analyzing all indicators of the impact factors and the factors that were affected individually; (ii) eliminating indicators which did not guarantee the technical requirements (indicator has two load coefficients with difference not greater than 0.2 , the indicator stood alone for a factor). The results are as follows:

Table 1: Results of Exploratory Factor Analysis - EFA. Source: Compiled from the analysis results - SPSS 16.0

\begin{tabular}{|c|c|c|c|}
\hline \multicolumn{2}{|r|}{ Factors } & Sign & $\begin{array}{l}\text { factor } \\
\text { loading }\end{array}$ \\
\hline \multicolumn{4}{|c|}{ Factors affecting with $\mathrm{KMO}=0,624$ and Cumulative $(\%)=70,152 \%$} \\
\hline \multirow{4}{*}{$\begin{array}{l}\text { Human factor - } \\
\text { accountants fac1-1 }\end{array}$} & $\begin{array}{l}\text { Accountants are not knowledgeable of the regulations on derivatives financial instrument } \\
\text { accounting }\end{array}$ & C19 & 0,817 \\
\hline & $\begin{array}{l}\text { Junior accountants are hardly able to handle difficult situations well, related to } \\
\text { derivatives financial instrument. }\end{array}$ & $\mathrm{C} 20$ & 0,752 \\
\hline & $\begin{array}{l}\text { The ability to understand derivatives financial instrument accounting applied to the } \\
\text { reality is still limited. }\end{array}$ & $\mathrm{C} 21$ & 0,733 \\
\hline & \begin{tabular}{|l|l} 
The ability to apply derivatives financial instrument accounting into reality is limited. \\
\end{tabular} & $\mathrm{C} 22$ & 0,850 \\
\hline \multirow{4}{*}{$\begin{array}{l}\text { Training - retraining } \\
\text { and technology- } \\
\text { communication } \\
\text { factors fac2-1 }\end{array}$} & $\begin{array}{l}\text { Consulting services related to the accounting of derivatives financial instrument are } \\
\text { regularly participated by enterprises }\end{array}$ & $\mathrm{C} 24$ & 0,796 \\
\hline & $\begin{array}{l}\text { Businesses regularly have planning and implementation of training and retraining } \\
\text { derivatives accounting for their staff and managers }\end{array}$ & $\mathrm{C} 27$ & 0,612 \\
\hline & $\begin{array}{l}\text { The growth rate of the information technology respond promptly to the accounting } \\
\text { system of the enterprise }\end{array}$ & $\mathrm{C} 28$ & 0,845 \\
\hline & $\begin{array}{l}\text { Accounting software ensures provide internal controls at the unit regularly monitor the } \\
\text { operation of accounting information systems on derivatives financial instrument }\end{array}$ & $\mathrm{C} 31$ & 0,679 \\
\hline \multirow{3}{*}{$\begin{array}{l}\text { Regulatory factor } \\
\text { fac3-1 }\end{array}$} & Ability to perform the accounting regulations on derivative financial instrumentss is low & $\mathrm{C} 12$ & 0,854 \\
\hline & $\begin{array}{l}\text { Ability to update the accounting provisions of derivative financial instrument is not in } \\
\text { time. }\end{array}$ & C13 & 0,684 \\
\hline & $\begin{array}{l}\text { The presentation of methods and principles in derivative financial instruments accounting } \\
\text { is not specific. }\end{array}$ & $\mathrm{C} 14$ & 0,898 \\
\hline \multirow{2}{*}{$\begin{array}{l}\text { Market factor } \\
\quad \text { fac4-1 }\end{array}$} & Participation in the capital market - the stock market is difficult for businesses. & $\mathrm{C} 10$ & 0,901 \\
\hline & Commodity market is lack of measurement standards in prices and in quality. & $\mathrm{C} 11$ & 0,893 \\
\hline \multirow{2}{*}{$\begin{array}{l}\text { Human factor - } \\
\text { managers fac5-1 }\end{array}$} & Accounting systems at enterprises lack the participation and cooperation of managers & C16 & 0,763 \\
\hline & $\begin{array}{l}\text { Managers are not aware of the importance of accounting information on derivatives } \\
\text { financial instruments }\end{array}$ & $\mathrm{C} 18$ & 0,878 \\
\hline \multicolumn{4}{|c|}{ Affected Factors with $\mathrm{KMO}=0,619$ and Cumulative $(\%)=60,174 \%$} \\
\hline \multirow{4}{*}{$\begin{array}{l}\text { Difficult factors in } \\
\text { application of } \\
\text { derivative financial } \\
\text { instruments } \\
\text { accounting fac1-2 }\end{array}$} & Enterprises often have difficulty in measurement after initial recognition & $\mathrm{C} 5$ & 0,806 \\
\hline & Enterprises often have difficulties in presenting derivative financial instruments & C6 & 0,906 \\
\hline & Enterprises often have difficulty in disclosuring derivative financial instruments & C7 & 0,615 \\
\hline & $\begin{array}{l}\text { Enterprises often have trouble with keeping derivative financial instruments in business } \\
\text { accounts. }\end{array}$ & $\mathrm{C} 8$ & 0,748 \\
\hline
\end{tabular}

The end result shows a perfectly fit data to perform factor analysis (KMO coefficients > 0.5 ; total variance extracted > 0.5 , and the load factor of the indicator elements $>0.5)$.
There are five factors that are separated from the six initial impact factors, and a factor that is affected by the indicators showing the affected factors. The researcher has named the factors based on the content of the indicator in the factors.

Table 2: Results of regression analysis. Source: The output results from SPSS 16.0

\begin{tabular}{|c|c|c|c|c|c|}
\hline \multirow{2}{*}{ Model } & \multicolumn{2}{|c|}{ Not standardized coefficients } & Standardized coefficients & \multirow{2}{*}{$t$} & \multirow{2}{*}{ Pvalue } \\
\cline { 2 - 5 } & Beta & Standard error & Beta & & \\
\hline 1 (constant) & $-4,818 \mathrm{E}-16$ & 0,059 & & 0,000 & 1,000 \\
\hline Human factor - accountants - fac1-1 & 0,121 & 0,059 & 0,121 & 2,041 & 0,044 \\
\hline $\begin{array}{c}\text { Training - training and technology - communication } \\
\text { factors - fac2-1 }\end{array}$ & $-0,023$ & 0,059 & $-0,023$ & $-0,381$ & 0,704 \\
\hline Regulatory factor fac3-1 & 0,815 & 0,059 & 0,815 & 13,766 & 0,000 \\
\hline Market factor - fac4-1 & 0,004 & 0,059 & 0,004 & 0,062 & 0,951 \\
\hline Human factor - managers fac5-1 & 0,042 & 0,059 & 0,042 & 0,717 & 0,475 \\
\hline
\end{tabular}

Dependent variable: Difficult factors in application of derivative financial instruments accounting

\section{Volume 5 Issue 6, June 2016 www.ijsr.net}

Licensed Under Creative Commons Attribution CC BY 


\section{International Journal of Science and Research (IJSR) \\ ISSN (Online): 2319-7064}

Index Copernicus Value (2013): 6.14 | Impact Factor (2015): 6.391

\subsection{Analysis correlation and regression}

The data used in the correlation regression analysis researchers selected was standardized. To determine the causal relationship between the variables in the model, the first step was that the author analyzed the relationship between the variables to find out if there was a multicollinearity phenomenon or not.

The results showed that the correlation coefficient $=0$, therefore, it's able to conclude that there's absolutely no signs of multicollinearity between the independent variables, and data perfectly suited for regression analysis.

The regression coefficients showed that each independent variable had different intensity impact on the dependent variable, namely (arranged in descending order of magnitude of the impact): regulatory factor FAC3-1, human factor accountants FAC1-1, the human factor - managers FAC5-1, market factor FAC4-1, which create positive impact; also factors of training, retraining and technological FAC1-1 negative impact causing difficulties in applying derivatives accounting at enterprises.

Results of regression coefficient with $\mathrm{R}^{2}=66.4 \%$, indicate that the model is capable of explaining $66.4 \%$ of the variation of the dependent variable (difficulties factors in the application of derivative accounting in the enterprises) by the independent variables included in the study model (regulatory factor; human factor - accountants; human factor - managers; market factor; training and retraining factors; and technological - communication - accounting software factors).

\subsection{The Results of Data Analysis and Discussion}

Research model has been tested with survey data reaching $66.4 \%$ level of explanation (corrected $\mathrm{R}^{2}=0.664$ ), the variables in the model are statistically significant. However, that one independent variable existed showed a negative impact on the dependent variables that are training, retraining, and technological - communication - accounting software factors.

- Factors of training, retraining and technology, communications, accounting software had negative impact on the dependent variable (with the average value of 2.3). This means that enterprises have no policy, or plans, or the training program for the staff to improve professional training and create additional human resources to serve legacy accounting work. Enterprises do not or can not meet the demand for accounting work, accounting software in the unit is not installed to respond in time to receive and transmit information related to derivatives financial instrument accounting. Therefore, these factors cause the difficulties in accounting work for enterprises.

- Regulatory factor (with average value 4.3) has the highest influence and positive impact on the dependent variable. This means that the absence of or shortage of regulations is a factor making accounting work difficult for enterprises.

- Human factor - accountants (with the average value of 3.7) shows positive impact on the dependent variable, which means that most accountants in the business do not meet the professional tasks and requirements, as well as expertise, awareness, understanding of derivative financial instruments. This is the main factor causing difficulties in applying derivative financial instruments accounting.

- Human factor - managers (with average value 4.3) has positive impact with lower intensity on the dependent variable. This also shows managers factor is a difficult factor when applying derivative accountin. The reason is that the managers may choose safety measures to avoid risks, which can lead to the managers' intentional impact on accounting systems, or managers will tend not to provide information on derivative financial instruments, or provide incomplete information to serve possibly their private purposes.

- Market factor (with the average value of 4.3) has positive influence on the dependent variable, with low intensity. It is understood that the capital market and commodity market have been formed and operated in Vietnam. But to make the markets work effectively, there must be participants - managers are the ones who give final decisions in all activities of the firm.

As stated above, accounting is considered to be a commodity to serve social interests, if managers are aware of the usefulness of accounting information, they may provide more information, which are more reliable, or transparent, the market participants will make business decisions more timely, and the market will run more efficiently.

In summary, through the analysis steps, the research model has identified factors affected including: measurement after initial recognition, presentation, disclosure, treament accounting for derivative financial instrument; and the factors causing impacts including: (i) regulatory factor having the most significant and positive impact are the low ability to implement accounting rules, the possibility of not timely updates, less detailed presentation of methods, materials and accounting rules; (ii) The human factor accountants with positive impacts including: accountants are not knowledgeable in accounting regulations, lack of experience in handling difficult situations, and has limited ability to understand and to apply in practice; (iii) the human factor - managers with the positive impact consist: accounting system lacks the participation and cooperation of managers, who are not aware of the importance of accounting information; (iv) market factor with positive impact: businesses' ability to enter the market is low; and (v) training and retraining; and technology, communication, accounting software factors with negative impact to be understood such as: consulting services related to the accounting for derivative financial instruments are not regularly participate, has no plans to carry out training and retraining for the accountants and managers, growth of information technology has not met in time for the accounting systems of enterprise, accounting software does not ensure adequate supply for internal control system.

\section{Conclusions and Implications}

Result of the testing model with reasonable explanatory coefficient $\left(\mathrm{R}^{2}=66.4 \%\right)$ reflects that the research model is quite consistent with the data and supported by the data. But a restriction still remains in the study result is its low 


\section{International Journal of Science and Research (IJSR) \\ ISSN (Online): 2319-7064}

Index Copernicus Value (2013): 6.14 | Impact Factor (2015): 6.391

reliability because of the small sample (due to objective conditions).

The objective of the study is to find out the factors in applying accounting for derivative financial instruments in Vietnam. Therefore, the results of the research must come up with policies and implications for accounting work, and simultaneusly to be the basis for the author's further studies on applying international accounting standards for derivative financial instrument in Vietnam accounting system.

To minimize the difficulties for businesses in accounting, in the current condition that the state has not issued accounting standards directly related to derivative financial instruments, according to research findings (from regression) and from the analysis above, the researcher proposed the following policies:

Based on the results of data analysis we can see there are five influencing factors requires timely policy stimulus to reduce the difficulties for accounting work. Details of the stimulus as follows:

1. Regulatory factor needs to be strengthened. Due to the accounting information is easyily bias in favour of the provider, the Ministry of Finance should soon issue regulations relating to derivative financial instruments in general and accounting for derivative financial instruments in particular fully and timely to promulgate or to apply international accounting standards. Also, specific provisions need to be understandable and consistent with the accounting standards related.

2. Human factor needs to be improved - Managers. Because accounting is a special commodity that related to social benefits, it should soon issue regulations directly related to the accounting of derivative financial instruments, strengthen the propaganda system to help managers see the importance of derivative financial instruments, as well as for the accounting work of derivative financial instruments at enterprises.

3. To minimize the difficulties for businesses in accounting, in the current confition that the state has not issued accounting standards directly related to derivative financial instruments, according to research findings (from regression) and from the analysis above, the researcher proposed the following policies:

4. Human factor - accountants, needs to be strengthened. To ensure social benefits accountants must be aware of the tasks, responsibilities and requirements of the Accounting Law provisions. Therefore, accountants must upgrade the level of expertise and skills in accounting. They are required to be ethical, responsible for compliance with the provisions of the law on accounting. Thus it helps to minimize the difficulties in accounting for the particular enterprises, and enhance the reputation of the professional community and accounting associations.

5. Factors of training, retraining and information technology, communications, accounting software: To minimize the difficulties in accounting work, enterprise need to actively do planning, provide training programs, and specialized knowledge to the staff involved. Also, they need to actively organize internal training or invite experts, or do research and create favorable conditions to participate in the market in order to achieve the highest efficiency for the accounting. The participants may be the administrators, the existing accountants, internal auditors, external auditor and a inheriting team to ensure that the accounting system runs smoothly and efficiently. In addition, enterprises are adivised to have innovation, accelerate the application of information technology, use of modern information networks by enhancing the system fitted to machinery and equipment accounting, networking systems, etc., to ensure that enterprises is operating in a smooth, seamless, and efficient. Accounting software system must be upgraded to ensure that accounting works promptly and fully. The computer must be equipped to receive and transmit information speedily and efficiently.

The research results helped authors draw implications and identify two key factors, such as regulatory factor and human factor - accountants. The implementation of policies specific to these two factors depends on many factors. Paper has successfully built up a research model and identified difficult factors. Data models are fully supported with high relevance.

However, due to objective conditions in Vietnam, the number of participating enterprises using derivatives are relatively low, enterprise accessing these instruments face many difficulties, while the respondents must be the ones understanding of derivatives, thereby the number of samples collected are relatively small (97 observations), the grouping of financial enterprises and non-financial has not been done. This can make the factors not highly reliable. At the same time, the research results can be the basis for further research direction that is the construction of accounting standards or the using international accounting standards for financial derivative instruments in Vietnam's accounting system.

\section{References}

[1] Bui Thi Kim Ngan. (2007). The solution developed derivatives market in Vietnam. Scientific seminar, 174182

[2] Davis et al (1982). The images that have shaped accounting theory. Accounting, Organizations and Society, 7(4), 307-18.

[3] Do Thi Kim Hao (2007). The solution developed derivatives market in Vietnam. Scientific seminar, 15-26

[4] Fatemi, A \& Luft, C. (2002). Corporate risk management: Costs and benefits. Global Finance Journal, 13(1), 29-38.

[5] Gonedes, N. J \& Dopuch, N. (1974). Capital Market Equilibrium, Information Production, and Selecting Accounting Techniques: Theoretical Framework and Review of Empirical Work. Journal of Accounting Research, 12, 48-129.

[6] Schofield, N.C. (2007). Commodity Derivatives Markets and Applications, John Wiley \& Sons Ltd.: London

[7] Spence, M. (1973). Job market signaling. Quarterly Journal of Economics, 87(3), 355-74. 


\section{International Journal of Science and Research (IJSR) \\ ISSN (Online): 2319-7064}

Index Copernicus Value (2013): 6.14 | Impact Factor (2015): 6.391

[8] Stamp, E. (1981). Why Can Accounting Not Become a Science Like Physics? ABACUS,17(1).

[9] Tirole, J. (1988). The theory of industrial organization. Cambridge. CA, MIT Press.

[10] Tran Thi Hong Hanh and Tran Thu Giang (2007). The solution developed derivatives market in Vietnam. Scientific seminar, 168-173

[11] Vietnam Accounting Law (2015)

[12] Wernerfelt. (1984). A resource-based view of the firm. Stragic Management Journal, 5, 171-80.

Volume 5 Issue 6, June 2016 www.ijsr.net 